\title{
Experimental Hall electron mobility of bulk single crystals of transparent semiconducting oxides
}

\author{
Zbigniew Galazka ${ }^{1, a)}$, Klaus Irmscher ${ }^{1}$, Mike Pietsch ${ }^{1}$, Steffen Ganschow ${ }^{1}$, Detlev Schulz ${ }^{1}$, \\ Detlef Klimm¹, Isabelle M. Hanke ${ }^{1}$, Thomas Schroeder ${ }^{1,2}$, Matthias Bickermann ${ }^{1,3}$ \\ ${ }^{1}$ Leibniz-Institut für Kristallzüchtung, Max-Born-Str. 2, 12489 Berlin, Germany \\ ${ }^{2}$ Institut für Physik, Humboldt-Universität zu Berlin, Newtonstr. 15, 12489 Berlin, Germany \\ ${ }^{3}$ Institut für Chemie, Technische Universität Berlin, Straße des 17. Juni 115, 10623 Berlin, Germany \\ a) Address all correspondence to this author. e-mail: zbigniew.galazka@ikz-berlin.de \\ Received: 8 April 2021; accepted: 16 August 2021; published online: 30 August 2021
}

\begin{abstract}
We provide a comparative study of basic electrical properties of bulk single crystals of transparent semiconducting oxides (TSOs) obtained directly from the melt (9 compounds) and from the gas phase ( 1 compound), including binary $\left(\mathrm{B}_{-} \mathrm{Ga}_{2} \mathrm{O}_{3}, \mathrm{In}_{2} \mathrm{O}_{3}, \mathrm{ZnO}, \mathrm{SnO}_{2}\right)$, ternary $\left(\mathrm{ZnSnO}_{3}, \mathrm{BaSnO}_{3}, \mathrm{MgGa}_{2} \mathrm{O}_{4}\right.$, $\left.\mathrm{ZnGa}_{2} \mathrm{O}_{4}\right)$, and quaternary $\left(\mathrm{Zn}_{1-\mathrm{x}} \mathrm{Mg}_{\mathrm{x}} \mathrm{Ga}_{2} \mathrm{O}_{4}, \mathrm{InGaZnO}_{4}\right)$ systems. Experimental outcome, covering over 200 samples measured at room temperature, revealed $n$-type conductivity of all TSOs with free electron concentrations $\left(n_{\mathrm{e}}\right)$ between $5 \times 10^{15}$ and $5 \times 10^{20} \mathrm{~cm}^{-3}$ and Hall electron mobilities $\left(\mu_{\mathrm{H}}\right)$ up to $240 \mathrm{~cm}^{2} \mathrm{~V}^{-1} \mathrm{~s}^{-1}$. The widest range of $n_{\mathrm{e}}$ values was achieved for $\beta-\mathrm{Ga}_{2} \mathrm{O}_{3}$ and $\ln _{2} \mathrm{O}_{3}$. The most electrically conducting bulk crystals are $\operatorname{InGaZnO}_{4}$ and $\mathrm{ZnSnO}_{3}$ with $n_{\mathrm{e}}>10^{20} \mathrm{~cm}^{-3}$ and $\mu_{\mathrm{H}}>100 \mathrm{~cm}^{2} \mathrm{~V}^{-1} \mathrm{~s}^{-1}$. The highest $\mu_{\mathrm{H}}$ values $>200 \mathrm{~cm}^{2} \mathrm{~V}^{-1} \mathrm{~s}^{-1}$ were measured for $\mathrm{SnO}_{2}$, followed by $\mathrm{BaSnO}_{3}$ and $\mathrm{In}_{2} \mathrm{O}_{3}$ single crystals. $\mathrm{In}_{2} \mathrm{O}_{3}, \mathrm{ZnO}, \mathrm{ZnSnO}_{3}$, and $\mathrm{InGaZnO}_{4}$ crystals were always conducting, while others could be turned into electrical insulators.
\end{abstract}

\section{Introduction}

Transparent semiconducting oxides (TSOs) combine semiconducting behaviour and high transparency in the visible spectrum, in some TSOs even down to the deep ultraviolet. They define a fast-growing area in solid-state physics that is relevant for both science and technology. Some of the physical properties of this class of materials, in particular transport properties thereof, are not fully understood so far, therefore, it opens an opportunity for fundamental studies of the physical properties. On the other hand, materials for study need to be obtained and this poses technological challenges, in particular when industrial applications are in quest. The TSO materials may have different forms, like nanocrystals, thin films, whether amorphous, polycrystalline, or crystalline, ceramics, and bulk single crystals. Although important properties can be gathered from ceramics and thin films they are usually affected by the composition, possible other phases, point defects, and structural defects. Due to their high structural quality and homogeneity, bulk single crystals show physical properties that are closer to intrinsic material properties than ceramics, nanocrystals, and most thin films.
Additionally, bulk single crystals serve as substrates for epitaxial growth and device fabrication.

There is a wide spectrum of applications for the TSOs, including electronics, opto-electronics, piezoelectrics, photovoltaics, radiation detection, gas sensing, catalysis, and the like, which may arise not necessarily from fundamental features of the TSOs, but also from the crystal structure and/ or surface properties. More details on the applications of the TSOs can be found e.g. in numerous review articles [1-10] and text books [11-16]. For some of these applications, especially for electronics, electrical properties of the materials are crucial for device operation. In particular, ultra-wide bandgaps of some of the TSOs make them suitable for high power switching devices, while materials with a very high electrical conductivity are well suited for transparent electrodes in photovoltaics and flat panel displays. Bulk crystals may function directly as active components in some of the devices (e.g. FET transistors and Schottky barrier diodes in vertical configurations) or as passive components acting as substrates for 
devices fabricated thereon. In the latter case, the substrates can be used for both homoepitaxy or heteroepitaxy.

A characteristic feature of the TSOs is the strong curvature of the bottom part of the conduction band (CB) enabling low electron effective mass of about $m_{e}^{*}=0.2-0.3 m_{0}$ for low to moderately high free electron concentrations $\left(<10^{20} \mathrm{~cm}^{-3}\right.$, where band filling effects may be neglected), where $m_{0}$ is the free electron mass, and relatively high electron mobility. On the other hand, the top part of the valence band (VB) is substantially flat resulting in high hole effective masses, which in combination with hole self-trapping phenomenon makes the holes almost immobile. Therefore, the TSOs are usually considered as effective n-type semiconductors.

In the present work, we focus on basic electrical properties of bulk TSO single crystals that we grew directly from the melt ( 9 compounds) and from the gas phase ( 1 compound). Experimental results obtained on a diversity of compounds frame a comparative study of the free electron concentrations and Hall electron mobilities of bulk TSO single crystals at room temperature (RT) that may serve as a guide for other forms of materials and different concepts of devices.

The bulk TSO single crystals discussed hereinafter are listed in Table 1, along with their basic structural properties, experimental bandgaps, and electron effective masses. The TSOs belong to different crystal systems, hence, they have different structures, and experimental bandgaps ranging between 2.7 and $4.9 \mathrm{eV}$. The bandgaps are typically direct or pseudo-direct as a result of the flatness of the VB maximum. A combination of structural, physical, and surface properties of the TSOs enables to design devices with unique functionalities.

\section{Bullk TSO single crystals}

All investigated bulk TSO single crystals were grown at the Leibniz-Institut für Kristallzüchtung, Berlin, Germany. They were grown directly from the melt except $\mathrm{SnO}_{2}$ that was obtained from the gas phase at high temperatures, as summarized in Table 2. The common features of the TSOs are high melting points and high thermal instability at high temperatures that makes the crystal growth directly from the melt really challenging. These challenges were addressed and bulk single crystals obtained, as discussed in our numerous works referenced in Table 2. High melting points of $1700-2100{ }^{\circ} \mathrm{C}$ require iridium crucibles for melt growth and high-quality refractory insulating materials. All TSOs are thermally unstable at such high temperatures leading to a substantial decomposition during growth. The most unstable compounds are those containing Sn, $\mathrm{Zn}$, and In elements. Ternary and quaternary systems proceed additionally incongruent decomposition (in terms of cations ratio). The growth of TSO single crystals directly from the melt requires therefore new scientific and technological approaches and concepts, as discussed in appended references in Table 2.

The size of obtained TSO single crystals varies depending on the compound, melting point, level of thermal instability, and the growth method. The largest bulk TSO single crystals were $\beta-\mathrm{Ga}_{2} \mathrm{O}_{3}$ (up to 2 inch in diameter and 4 inch in length) and $\mathrm{ZnO}$ (33 $\mathrm{mm}$ in diameter and $40 \mathrm{~mm}$ in length), while the smallest were $\mathrm{ZnSnO}_{3}$ and $\mathrm{InGaZnO}_{4}$ with the size of several $\mathrm{mm}$. The structural quality of most of the discussed TSO single crystals can be found in references depicted in Table 2 .

The investigated samples were prepared from as-grown, annealed, and in some cases from intentionally doped crystals. Annealing and doping aimed to modify electrical properties of as-grown or undoped crystals, respectively. Undoped crystals

TABLE 1: Investigated bulk TSO single crystals, their crystal structures, optical bandgaps measured on bulk crystals at room temperature (RT), and electron effective masses near the conduction band minimum.

\begin{tabular}{|c|c|c|c|c|}
\hline Compound & Crystal system, space group & Experimental lattice parameters $[\AA ̊]$ & $\begin{array}{c}\text { Experimental optical } \\
\text { bandgap }[\mathrm{eV}]\end{array}$ & Electron effective mass $m_{e}^{*} / m_{0}$ \\
\hline$\beta-\mathrm{Ga}_{2} \mathrm{O}_{3}$ & Monoclinic, $C 2 / m$ & $\begin{array}{l}a=12.2290, b=3.0390 \\
c=5.8035, \beta=103.82^{\circ}\end{array}$ & $4.85[10]$ & $0.26-0.28^{(\mathrm{e})}[17]$ \\
\hline $\ln _{2} \mathrm{O}_{3}$ & Cubic, $l a \overline{3}$ & $a=10.1212[16]$ & $2.72[18]$ & $0.19-0.46^{(e)}[19]$ \\
\hline $\mathrm{ZnO}$ & Hexagonal, $P 6_{3} m c$ & $a=3.253, c=5.213[20]$ & $3.18[16]$ & $0.23-0.32^{(\mathrm{e})}[21-25]$ \\
\hline $\mathrm{SnO}_{2}$ & Tetragonal, $P 4_{2} \mathrm{mnm}$ & $a=4.7374, c=3.1864[26]$ & $3.77[16]$ & $0.2-0.39^{(\mathrm{e})}[27,28]$ \\
\hline $\mathrm{ZnSnO}_{3}$ & Trigonal, $R 3 c$ & $a=5.2622, c=14.0026[29]$ & $3.90[30]$ & $0.32^{(t)}[31]$ \\
\hline $\mathrm{BaSnO}_{3}$ & Cubic, $P m \overline{3} m$ & $a=4.117[32]$ & $2.99[33]$ & $0.19-0.36^{(\mathrm{e})}[34,35]$ \\
\hline $\mathrm{MgGa}_{2} \mathrm{O}_{4}$ & Cubic, Fd $\overline{3} m$ & $a=8.281[36]$ & $4.90[37]$ & $0.28-0.31^{(\mathrm{t})}[16]$ \\
\hline $\mathrm{Zn}_{1-x} \mathrm{Mg}_{\mathrm{x}} \mathrm{Ga}_{2} \mathrm{O}_{4}$ & Cubic, Fd $\overline{3} m$ & - & $4.75[38]$ & - \\
\hline $\mathrm{ZnGa}_{2} \mathrm{O}_{4}$ & Cubic, Fd $\overline{3} m$ & $a=8.3336[39]$ & $4.59[39]$ & $0.21-0.25^{(\mathrm{t})}[40,41]$ \\
\hline $\operatorname{lnGaZnO}{ }_{4}$ & Trigonal, $R \overline{3} m$ & $a=3.275, c=25.99[42]$ & 3.54 & $0.25-0.26^{(\mathrm{t})}[43]$ \\
\hline
\end{tabular}

Superscripts (e) and (t) refer to experimental (both bulk crystals and thin films) and theoretical values, respectively. Theoretical values for the electron effective masses were used when experimental ones were not available according to the author's best knowledge. 
TABLE 2: Growth methods along with melting points and investigated samples of bulk TSO single crystals grown from the melt (all except $\mathrm{SnO}_{2}$ ) and from the gas phase $\left(\mathrm{SnO}_{2}\right)$.

\begin{tabular}{|c|c|c|c|c|}
\hline Compound & Melting point $\left[{ }^{\circ} \mathrm{C}\right]$ & Growth method & $\begin{array}{l}\text { References for bulk TSO } \\
\text { crystal growth }\end{array}$ & Investigated samples \\
\hline$\beta-\mathrm{Ga}_{2} \mathrm{O}_{3}$ & $1793^{*}$ & Czochralski & {$[10,16,38,44-50]$} & $\begin{array}{l}\text { As-grown, annealed, doped ( } \mathrm{Si}, \mathrm{Sn}, \mathrm{Ge}, \mathrm{Ce}, \mathrm{Al}, \mathrm{Cr} \text {, } \\
\mathrm{Mg}, \mathrm{Ni}, \mathrm{Co}, \mathrm{Cu}, \mathrm{Li} \text {, and combinations of some of } \\
\text { them) }\end{array}$ \\
\hline $\ln _{2} \mathrm{O}_{3}$ & $1950 \pm 30$ & LASSCGM & {$[16,51-53]$} & As-grown, annealed \\
\hline $\mathrm{ZnO}$ & 1975 & Bridgman & [54-58] & As-grown, annealed \\
\hline $\mathrm{SnO}_{2}$ & $>2100$ & PVT & {$[16,59]$} & As-grown, annealed \\
\hline $\mathrm{ZnSnO}_{3}$ & $1750 \pm 25$ & VGF & [60] & As-grown \\
\hline $\mathrm{BaSnO}_{3}$ & $1855 \pm 25$ & VGF & {$[16,33]$} & As-grown, doped (La) \\
\hline $\mathrm{MgGa}_{2} \mathrm{O}_{4}$ & $1930 \pm 10$ & $\begin{array}{l}\text { Czochralski, Bridgman, } \\
\text { Kyropoulos-like }\end{array}$ & {$[16,37,38]$} & As-grown, annealed, doped (Si) \\
\hline $\mathrm{Zn}_{1-\mathrm{x}} \mathrm{Mg}_{\mathrm{x}} \mathrm{Ga}_{2} \mathrm{O}_{4}$ & $1920 \pm 20$ & VGF & {$[16,38]$} & As-grown, annealed \\
\hline $\mathrm{ZnGa}_{2} \mathrm{O}_{4}$ & $1900 \pm 20$ & VGF & {$[16,38,39]$} & As-grown, annealed, doped ( $\mathrm{Si}, \mathrm{Zr}, \mathrm{Y})$ \\
\hline $\mathrm{InGaZnO}_{4}$ & $1700 \pm 30$ & VGF & [61] & As-grown, annealed \\
\hline
\end{tabular}

LASSCGM levitation-assisted self-seeding crystal growth method, PVT physical vapour transport, VGF vertical gradient freeze.

*From Ref. [62].

means crystals without any intentional doping when using good purity powders (typically $5 \mathrm{~N}$ or $4 \mathrm{~N}$ in some cases) as the starting materials. Annealing was performed in the presence of oxygen or hydrogen-containing atmospheres at temperatures up to $1200{ }^{\circ} \mathrm{C}$ and $800^{\circ} \mathrm{C}$, respectively, for $1 \mathrm{~h}$ to $20 \mathrm{~h}$. Lower annealing temperature in the case of hydrogen-containing atmospheres was necessary to avoid reduction action of hydrogen that causes a sample damage at higher temperatures. On the other hand, the TSOs are thermodynamically stable up to $1200^{\circ} \mathrm{C}$ in oxygencontaining atmospheres. Doping elements were selected for a specific compound to either enhance or compensate the electrical conductivity.

\section{Electrical characterization}

The electrical conductivity and Hall effect of the crystals were measured in van der Pauw configuration at room temperature using a Hall measurement system HMS 7504 (Lake Shore). The contacts of diameters less than $0.5 \mathrm{~mm}$ were prepared by rubbing a little In-Ga eutectic mixture in the corners of quadratic (or rectangular) wafer samples of typically $5 \times 5$ (or 3 ) $\times 0.5 \mathrm{~mm}^{3}$ in size. Ohmic behaviour of these contacts was accomplished by discharging a capacitor over each two contacts, i.e. contact forming by local alloying, since otherwise, too high contact resistances and/or non-linear current-voltage characteristics prevented reliable Hall effect measurements. Electrical set-up and sample dimensions limited resistivity measurements to values up to about $10^{8} \Omega \mathrm{cm}$. Therefore, samples with higher resistivity could not be measured and are indicated as electrical insulators. Electron concentration and electron mobility were calculated under the assumption of a unity Hall scattering factor.
The accuracy of these values is mainly determined by the errors introduced by electrical inhomogeneities due to unintentional doping variations and structural defects (see discussion below). Our experience with collecting the big data set presented hereinafter let us estimate the deviation from the given values to be below $20-30 \%$.

All the investigated bulk TSO single crystals showed n-type conductivity. As listed in Table 3, some of the TSOs

TABLE 3: Electrical conductivity states at room temperature of bulk TSO single crystals grown from the melt (all except $\mathrm{SnO}_{2}$ ) and from the gas phase $\left(\mathrm{SnO}_{2}\right)$.

\begin{tabular}{|c|c|c|c|}
\hline Compound & $\begin{array}{l}\text { Electrically } \\
\text { insulating }\end{array}$ & Insulating state obtained by & $\begin{array}{l}\text { Con- } \\
\text { ducting } \\
\text { (as- } \\
\text { grown) }\end{array}$ \\
\hline$\beta-\mathrm{Ga}_{2} \mathrm{O}_{3}$ & Yes & $\begin{array}{l}\text { High } \mathrm{O}_{2} \text { in the growth atmos- } \\
\text { phere and/or doping with } \\
\text { divalent ions }\end{array}$ & Yes \\
\hline $\ln _{2} \mathrm{O}_{3}$ & No & - & Yes \\
\hline $\mathrm{ZnO}$ & No & - & Yes \\
\hline $\mathrm{SnO}_{2}$ & Yes & $\begin{array}{l}\text { Annealing in the presence } \\
\text { of } \mathrm{O}_{2}\end{array}$ & Yes \\
\hline $\mathrm{ZnSnO}_{3}$ & No & - & Yes \\
\hline $\mathrm{BaSnO}_{3}$ & Yes & $\begin{array}{l}\text { High } \mathrm{O}_{2} \text { in the growth atmos- } \\
\text { phere }\end{array}$ & Yes \\
\hline $\mathrm{MgGa}_{2} \mathrm{O}_{4}$ & Yes & $\begin{array}{l}\text { High } \mathrm{O}_{2} \text { in the growth atmos- } \\
\text { phere or annealing in the } \\
\text { presence of } \mathrm{O}_{2}\end{array}$ & Yes \\
\hline $\mathrm{Zn}_{1-\mathrm{x}} \mathrm{Mg}_{\mathrm{x}} \mathrm{Ga}_{2} \mathrm{O}_{4}$ & Yes & $\begin{array}{l}\text { Annealing in the presence } \\
\text { of } \mathrm{O}_{2}\end{array}$ & Yes \\
\hline $\mathrm{ZnGa}_{2} \mathrm{O}_{4}$ & Yes & $\begin{array}{l}\text { Annealing in the presence } \\
\text { of } \mathrm{O}_{2}\end{array}$ & Yes \\
\hline $\mathrm{InGaZnO}_{4}$ & No & - & Yes \\
\hline
\end{tabular}


can be obtained as electrical insulators. This was achieved either by high oxygen partial pressure in the growth atmosphere $\left(\beta-\mathrm{Ga}_{2} \mathrm{O}_{3}, \mathrm{BaSnO}_{3}, \mathrm{MgGa}_{2} \mathrm{O}_{4}\right)$ and/or intentional doping $\left(\beta-\mathrm{Ga}_{2} \mathrm{O}_{3}\right.$ doped with $\left.\mathrm{Mg}, \mathrm{Ni}, \mathrm{Co}\right)$, or post growth heat treatment in the presence of oxygen at temperatures typically above $700{ }^{\circ} \mathrm{C}\left(\mathrm{SnO}_{2}\right.$ and $\mathrm{Ga}$-based spinels, i.e. $\mathrm{MgGa}_{2} \mathrm{O}_{4}$, $\mathrm{ZnGa}_{2} \mathrm{O}_{4}$, and $\mathrm{Zn}_{1-\mathrm{x}} \mathrm{Mg}_{\mathrm{x}} \mathrm{Ga}_{2} \mathrm{O}_{4}$,). Bulk single crystals of $\mathrm{In}_{2} \mathrm{O}_{3}, \mathrm{ZnO}, \mathrm{ZnSnO}_{3}$, and $\mathrm{InGaZnO}_{4}$ were always electrically conducting independent on annealing (although it decreased the free electron concentration less than one order of magnitude). Bulk $\mathrm{ZnO}, \mathrm{SnO}_{2}$, and $\mathrm{MgGa}_{2} \mathrm{O}_{4}$ crystals could not reach highly conducting state $\left(>5 \times 10^{18} \mathrm{~cm}^{-3}\right)$, while bulk $\mathrm{ZnSnO}_{3}$ and $\mathrm{InGaZnO}_{4}$ single crystals were always highly conducting, even after annealing in the presence of oxygen.

Sources of the electrical conductivity of some of the TSOs as such have intensively been studied by numerous researchers both theoretically and experimentally. Although solid conclusions were drawn in some cases, ambiguity in other cases remain. For instance, the electrical conductivity in $\beta-\mathrm{Ga}_{2} \mathrm{O}_{3}$ may arises from solid impurities present in the starting material/intentional doping ( $\mathrm{Si}, \mathrm{Sn}, \mathrm{Ge}, \mathrm{Zr}, \mathrm{Hf})$ and hydrogen $[48,63-68]$; in $\operatorname{In}_{2} \mathrm{O}_{3}$ from impurities/intentional doping ( $\mathrm{Sn}, \mathrm{Ti}, \mathrm{Zr}$ ), fluorine, hydrogen, and possible oxygen vacancies [69-72]; in $\mathrm{ZnO}$ from impurities/intentional doping (such as $\mathrm{Al}, \mathrm{Ga}, \mathrm{In}, \mathrm{Sc}$ ), $\mathrm{Zn}$ interstitials, hydrogen, complexes [73-76]; in $\mathrm{SnO}_{2}$ from solid impurities/intentional doping (such as $\mathrm{Sb}$, As), fluorine, hydrogen [77-80]; in $\mathrm{BaSnO}_{3}$ from intentional doping ( $\mathrm{La}, \mathrm{Y}, \mathrm{Pr}, \mathrm{Nd}, \mathrm{Sb}$ ), fluorine, and hydrogen [81-84]. Here we point out that the growth of bulk TSO single crystals at very high temperatures combined with high thermal instability (decomposition) might generate structural and intrinsic point defects that influence electrical properties to some extent. As an example, at high temperatures during growth, the cation distribution for all spinels is random, but becomes inverse $\left(\mathrm{MgGa}_{2} \mathrm{O}_{4}\right)$ or normal $\left(\mathrm{ZnGa}_{2} \mathrm{O}_{4}\right)$ at room temperature. However, not slow enough cooling may preserve antisite defects $\left(\mathrm{Ga}_{\mathrm{Mg}}, \mathrm{Ga}_{\mathrm{Zn}}\right)$ in such systems, giving rise to electrical conductivity at RT. Antisite defects with low formation energy in $\mathrm{ZnGa}_{2} \mathrm{O}_{4}$ have already been theoretically predicted [85]. Similarly, electrical conductivity in $\mathrm{ZnSnO}_{3}\left(\mathrm{Sn}_{\mathrm{Zn}}\right)$ and $\mathrm{InGaZnO}_{4}\left(\mathrm{Ga}_{\mathrm{Zn}}\right)$ crystals may be induced due to incongruent decomposition and evaporation, as for instance concluded from the theory for $\mathrm{InGaZnO}_{4}$ [86]. In addition, impurities present even in high-purity starting materials as well as in iridium crucibles, and thermal insulation may also contribute to electrical conductivity of these materials. For that reason, we do not discuss hereinafter the sources of the electrical conductivity in these materials as it requires a separate, long-lasting study. Instead, we provide an experimental output gathered from bulk crystals grown at high temperatures.
The ranges of the free electron concentration in conducting bulk TSO single crystals are presented in Fig. 1. The widest range of the free electron concentrations, covering more than three orders of magnitude, was obtained for bulk $\beta-\mathrm{Ga}_{2} \mathrm{O}_{3}$ single crystals. The next one is $\mathrm{In}_{2} \mathrm{O}_{3}$ with over two, and $\mathrm{BaSnO}_{3}$ with about two orders of magnitude. Bulk $\mathrm{ZnO}$ and $\mathrm{MgGa}_{2} \mathrm{O}_{4}$ crystals showed the lowest span in the free electron concentrations, below one order of magnitude. High values of the free electron concentrations $>10^{19} \mathrm{~cm}^{-3}$ were measured for bulk $\mathrm{BaSnO}_{3}$ (doped with La), as well as for $\mathrm{ZnSnO}_{3}, \mathrm{In}_{2} \mathrm{O}_{3}, \mathrm{ZnGa}_{2} \mathrm{O}_{4}$, and In $\mathrm{GaZnO}_{4}$ (all undoped) single crystals. The compounds that revealed the highest free electron concentrations $>10^{20} \mathrm{~cm}^{-3}$ are bulk $\mathrm{ZnSnO}_{3}$ and $\mathrm{InGaZnO}_{4}$ single crystals. Since bulk crystal growth, in particular from the melt, proceeds near thermodynamic equilibrium, the incorporation of dopants is much more limited by solubility constraints than it is the case in thin film growth. Furthermore, during cooling down of highly doped bulk crystals from the growth (melt) temperature to room temperature precipitation of dopants may take place as long as dopant diffusion is not frozen. Precipitations may lead, in turn, to the formation of other defects, such as dislocations. In general, high doping with foreign atoms disturbs single-crystal growth and results in a deteriorated structural quality. In most cases, structural defects are electrically active and in TSOs they act as acceptors compensating intentionally introduced donors. Another issue with the growth near thermodynamic equilibrium is that in wide bandgap semiconductors, as the TSOs are, self-compensation cannot effectively be suppressed. Either the

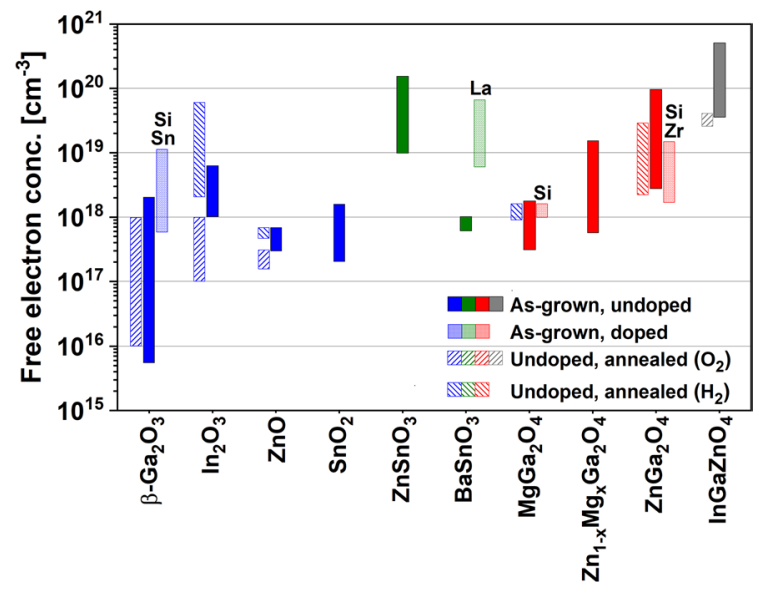

Figure 1: Range of the free electron concentrations at RT in bulk TSO single crystals grown from the melt (all except $\mathrm{SnO}_{2}$ ) and from the gas phase $\left(\mathrm{SnO}_{2}\right)$. Binary systems are shown in blue, perovskites in green, Ga-based spinels in red, and the quaternary system $\mathrm{InGaZnO}_{4}$ in grey. Dopants which turned to crystals into electrically insulating state or substantially had no impact on the electrical properties $\left(\beta-\mathrm{Ga}_{2} \mathrm{O}_{3}\right.$ case) are not included. Annealing Ga-based spinels in the presence of oxygen, which turned the crystals into electrically insulating state, are not included as well. Annealed $\left(\mathrm{O}_{2}\right)$ and $\left(\mathrm{H}_{2}\right)$ refer to annealing in the presence of oxygen and hydrogen, respectively. 
doping atom enters different lattice sites where it acts as donor or acceptor, or its incorporation favours the formation of compensating intrinsic defects (e.g. cation vacancies). On the other hand, the free electron concentration can be higher in thin films than that in bulk crystals shown in Fig. 1. For instance, the free electron concentration in $\beta-\mathrm{Ga}_{2} \mathrm{O}_{3}$ films grown by metal organic vapour phase epitaxy (MOVPE) was reported at a level of $8 \times 10^{19} \mathrm{~cm}^{-3}$ [87], in $\mathrm{In}_{2} \mathrm{O}_{3}$ films grown by molecular beam epitaxy (MBE) of $2 \times 10^{21} \mathrm{~cm}^{-3}$ [88], in $\mathrm{ZnO}$ films grown by $\mathrm{MBE}$ of $4.1 \times 10^{19} \mathrm{~cm}^{-3}$ [89], in $\mathrm{SnO}_{2}$ films grown by $\mathrm{MBE}$ of $2.6 \times 10^{20}$ [90], and in $\mathrm{BaSnO}_{3}$ films grown by laser ablation of $\sim 10^{21} \mathrm{~cm}^{-3}$ [91].

The essence of the present work is shown in Fig. 2 describing an experimental relation between the Hall electron mobility $\mu_{\mathrm{H}}$ and free electron concentration $n_{\mathrm{e}}$ in the log-log scale. Generally, at moderate and low $n_{\mathrm{e}}$ values $\left(<10^{18} \mathrm{~cm}^{-3}\right) \mu_{\mathrm{H}}$ is limited by phonon scattering, which is defined by the compound and its crystal structure. On the other hand, at high $n_{\mathrm{e}}$ values $\left(>10^{18} \mathrm{~cm}^{-3}\right) \mu_{\mathrm{H}}$ is limited by impurity scattering. This is why one may expect a gradual decrease of $\mu_{\mathrm{H}}$ with $n_{\mathrm{e}}$ if these two scattering mechanisms dominate. This relation is met by the binary systems $\beta-\mathrm{Ga}_{2} \mathrm{O}_{3}, \mathrm{In}_{2} \mathrm{O}_{3}, \mathrm{ZnO}$, and $\mathrm{SnO}_{2}$. It should be stressed, however, that the electron mobility is affected not only by the phonon and impurity scattering, but also by scattering on structural (dislocations, stacking faults, precipitations, grain boundaries, twins, etc.) and point (vacancies, interstitials, substitutions, complexes, impurities, etc.) defects that can be present in bulk crystals at different concentrations. This can be seen by data scattering in Fig. 2. For instance, the data scattering range of $\beta-\mathrm{Ga}_{2} \mathrm{O}_{3}$ and $\mathrm{ZnO}$ is narrow indicating high structural quality of the crystals, while it is wider for $\mathrm{SnO}_{2}$ and $\mathrm{In}_{2} \mathrm{O}_{3}$ crystals, which indeed, often showed either low-angle grain boundaries as the result of the growth from the gas phase $\left(\mathrm{SnO}_{2}\right)$ or the

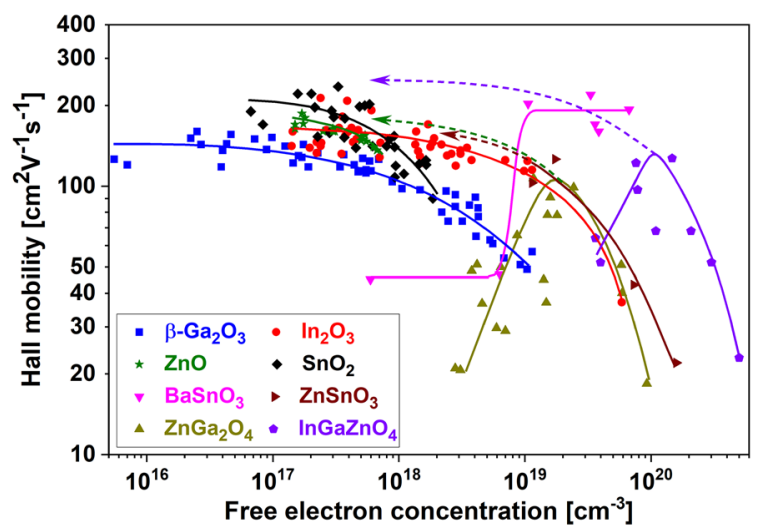

Figure 2: Log-log relation between Hall electron mobility and the free electron concentration at RT for bulk TSO single crystals grown from the melt (all except $\mathrm{SnO}_{2}$ ) and from the gas phase $\left(\mathrm{SnO}_{2}\right)$. The solid lines refer to the measured values, while dashed lines to extrapolations assuming a similar trend to binary compounds (i.e. phonon scattering limitation). formation oxygen vacancy clusters, being actually metallic In clusters, in $\mathrm{In}_{2} \mathrm{O}_{3}$ [92].

Among ternary $\left(\mathrm{ZnGa}_{2} \mathrm{O}_{4}, \mathrm{MgGa}_{2} \mathrm{O}_{4}, \mathrm{BaSnO}_{3}\right.$, and $\left.\mathrm{ZnSnO}_{3}\right)$ and quaternary $\left(\mathrm{Zn}_{1-\mathrm{x}} \mathrm{Mg}_{\mathrm{x}} \mathrm{Ga}_{2} \mathrm{O}_{4}, \mathrm{InGaZnO}_{4}\right)$ compounds only $\mathrm{ZnSnO}_{3}$ show a similar trend to binary compounds, but it is based on fewer number of measured samples having only high values of electron concentration. Other compounds within this group show a different behaviour.

A reverse $\mu_{\mathrm{H}}-n_{\mathrm{e}}$ relation at lower doping level of $\mathrm{ZnGa}_{2} \mathrm{O}_{4}$ $\left(n_{\mathrm{e}}<2 \times 10^{19} \mathrm{~cm}^{-3}\right)$ is likely defect related. In fact, we observed inside the crystals nanoparticles of metallic nature [39] that might form nano-Schottky contacts with the semiconducting host material resulting in charge carrier depletion zones around them with increasing extension at lower $n_{\mathrm{e}}$ leading eventually to complete blocking of current flow and apparent mobility collapse. In contrast, the depletion zones shrink with increasing $n_{\mathrm{e}}$ and allow current flow which eventually is limited by ionized impurity scattering. Both effects make a bell-like shape of the $\mu_{\mathrm{H}}-n_{\mathrm{e}}$ relation. Reducing or eliminating the nanoparticles in bulk $\mathrm{ZnGa}_{2} \mathrm{O}_{4}$ crystals may increase $\mu_{\mathrm{H}}$ values to high levels (about $200 \mathrm{~cm}^{2} \mathrm{~V}^{-1} \mathrm{~s}^{-1}$ ) at low $n_{\mathrm{e}}$ values, as indicated by the dashed line in Fig. 2. Moreover, as intentional dopant concentration in $\mathrm{ZnGa}_{2} \mathrm{O}_{4}$ crystals is lower than the $n_{\mathrm{e}}$ concentration, that possibly arises from antisite defects [38], intentional doping might not be effective. A similar shape of the $\mu_{\mathrm{H}}-n_{\mathrm{e}}$ relation is also obtained for $\mathrm{InGaZnO}_{4}$ in which we found inclusions of the secondary phase $\mathrm{In}_{2} \mathrm{Ga}_{2} \mathrm{ZnO}_{7}$. The formation of this secondary phase was also pointed out during growth of $\mathrm{InGaZnO}_{4}$ single crystals by the Optical Floating Zone method at a low gas pressure [93]. Also, $\mathrm{ZnSnO}_{3}$ crystals contained traces of the secondary phase $\mathrm{Zn}_{2} \mathrm{SnO}_{4}$. Single crystals of $\mathrm{MgGa}_{2} \mathrm{O}_{4}$ (not shown in Fig. 2) showed low $\mu_{\mathrm{H}}$ values of $4-7 \mathrm{~cm}^{2} \mathrm{~V}^{-1} \mathrm{~s}^{-1}$ [38]), while $\mathrm{Zn}_{1-\mathrm{x}} \mathrm{Mg}_{\mathrm{x}} \mathrm{Ga}_{2} \mathrm{O}_{4}$ (not shown in Fig. 2) an increase of $\mu_{\mathrm{H}}$ with $n_{\mathrm{e}}$ in the range of $8-32 \mathrm{~cm}^{2} \mathrm{~V}^{-1} \mathrm{~s}^{-1}$, which is the result of an increase of $\mathrm{Zn}$ in favour of $\mathrm{Mg}$ concentrations [38]).

Bulk $\mathrm{BaSnO}_{3}$ single crystals present a special case. When undoped or La-doped at low level, $n_{\mathrm{e}}<10^{19} \mathrm{~cm}^{-3}, \mu_{\mathrm{H}}$ values are low, about $50 \mathrm{~cm}^{2} \mathrm{~V}^{-1} \mathrm{~s}^{-1}$. The situation drastically changes with higher La-doping levels $\left(n_{\mathrm{e}}>10^{19} \mathrm{~cm}^{-3}\right)$, when Hall mobility jumps to high values, about or above $200 \mathrm{~cm}^{2} \mathrm{~V}^{-1} \mathrm{~s}^{-1}$. High electron mobility at high free electron concentrations has been explained by a physical separation of the doping sites $\left(\mathrm{La}^{3+}\right.$ replaces $\mathrm{Ba}^{2+}$ in the Ba-subnetwork) and conduction channel (Sn-subnetwork) that minimizes scattering at ionized impurities, high dispersion of the bottom part of the conduction band enabling high mobility, low effective electron mass, and high dielectric constant that enhances scattering screening arising from different sources $[35,83,102,103]$. The highest reported $\mu_{\mathrm{H}}$ value for flux-grown La-doped $\mathrm{BaSnO}_{3}$ single crystals is $320 \mathrm{~cm}^{2} \mathrm{~V}^{-1} \mathrm{~s}^{-1}$ [102]. Doping the conduction channel (Snsubnetwork) with $\mathrm{Sb}$ resulted, indeed, with much lower $\mu_{\mathrm{H}}$ 
values, below $100 \mathrm{~cm}^{2} \mathrm{~V}^{-1} \mathrm{~s}^{-1}$ [83]. Similar situation may be expected for other ternary and quaternary systems, in particular for $\mathrm{ZnSnO}_{3}, \mathrm{ZnGa}_{2} \mathrm{O}_{4}$, and $\mathrm{InGaZnO}_{4}$ single crystals when of high crystalline perfection. Indeed, these compounds revealed relatively high $\mu_{\mathrm{H}}>100 \mathrm{~cm}^{2} \mathrm{~V}^{-1} \mathrm{~s}^{-1}$ at high $n_{\mathrm{e}}>10^{19} \mathrm{~cm}^{-3}$. We would like to stress, however, that $\mathrm{BaSnO}_{3}$ crystals grown from the melt also contains nanoparticles of metallic nature that may significantly decrease the electron mobility at low doping level, in a similar way to $\mathrm{ZnGa}_{2} \mathrm{O}_{4}$ discussed above.

The difference in the $\mu_{\mathrm{H}}-n_{\mathrm{e}}$ relation between the discussed binary and ternary/quaternary systems seems to be related to a higher probability of the formation of both structural and point defects in the latter case, as discussed above. Two and three cations in the ternary and quaternary systems, respectively, increase the degree of freedom of various defect

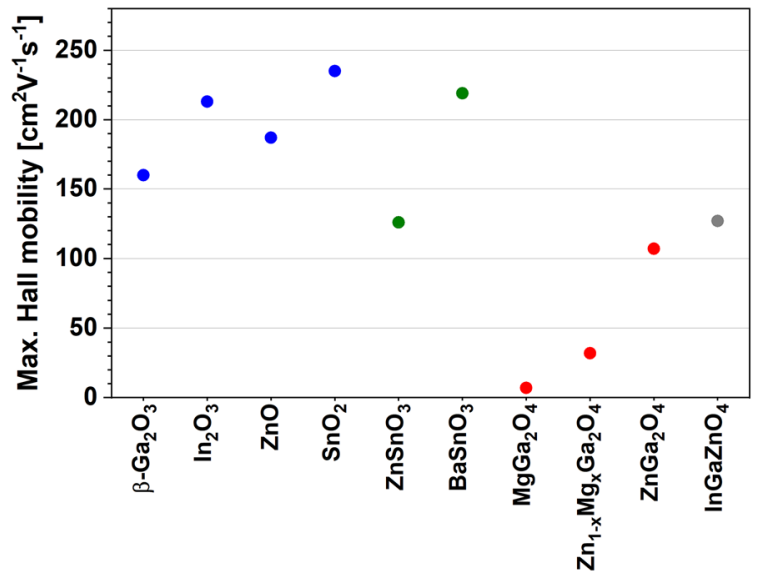

Figure 3: Maximum values of the Hall electron mobility at RT measured on bulk TSO single crystals grown from the melt (all except $\mathrm{SnO}_{2}$ ) and from the gas phase $\left(\mathrm{SnO}_{2}\right)$. Binary systems are shown in blue, perovskites in green, Ga-based spinels in red, and the quaternary system InGaZnO in grey. formation, which is enhanced by different partial pressures of cation-containing species leading to a fast composition shift during growth from the melt at high temperatures. Reduction of the defect density affecting the electrical properties in the ternary/quaternary systems, which is a really challenging task, would bring the $\mu_{\mathrm{H}}-n_{\mathrm{e}}$ relation closer to that of the binary systems with high Hall mobilities $\left(>150 \mathrm{~cm}^{2} \mathrm{~V}^{-1} \mathrm{~s}^{-1}\right)$ at low $n_{\mathrm{e}}$ values, as indicated by extrapolated dashed lines in Fig. 2 .

Finally, Fig. 3 demonstrates a comparison of maximum $\mu_{\mathrm{H}}$ $\left(\mu_{\mathrm{H}-\mathrm{Max}}\right)$ values of the discussed bulk TSO single crystals we measured. Out of 10 compounds, the highest $\mu_{\mathrm{H}-\mathrm{Max}}$ values, above $200 \mathrm{~cm}^{2} \mathrm{~V}^{-1} \mathrm{~s}^{-1}$, are shown by $\mathrm{SnO}_{2}, \mathrm{BaSnO}_{3}$, and $\mathrm{In}_{2} \mathrm{O}_{3}$. Within a lower range of $150-200 \mathrm{~cm}^{2} \mathrm{~V}^{-1} \mathrm{~s}^{-1}$ are $\beta-\mathrm{Ga}_{2} \mathrm{O}_{3}$ and $\mathrm{ZnO}$, between 100 and $150 \mathrm{~cm}^{2} \mathrm{~V}^{-1} \mathrm{~s}^{-1}$ are $\mathrm{ZnSnO}_{3}, \mathrm{ZnGa}_{2} \mathrm{O}_{4}$, and $\mathrm{InGaZnO}_{4}$, while below $100 \mathrm{~cm}^{2} \mathrm{~V}^{-1} \mathrm{~s}^{-1}$ are Ga-based spinels containing $\mathrm{Mg}$, i.e. $\mathrm{MgGa}_{2} \mathrm{O}_{4}$ and $\mathrm{Zn}_{1-\mathrm{x}} \mathrm{Mg}_{\mathrm{x}} \mathrm{Ga}_{2} \mathrm{O}_{4}$. The record $\mu_{\mathrm{H}-\mathrm{Max}}=240 \mathrm{~cm}^{2} \mathrm{~V}^{-1} \mathrm{~s}^{-1}$ belongs to undoped $\mathrm{SnO}_{2}$, also $\mathrm{La}$-doped $\mathrm{BaSnO}_{3}$ showed similar value of $225 \mathrm{~cm}^{2} \mathrm{~V}^{-1} \mathrm{~s}^{-1}$. It seems that Sn-subnetwork in a crystal lattice enables a good electron transport with a high mobility. Undoped $\mathrm{ZnSnO}_{3}$ shows lower mobility than La-doped $\mathrm{BaSnO}_{3}$, but better than ed $\mathrm{BaSnO}_{3}$ [33]. The transport mechanism in undoped $\mathrm{ZnSnO}_{3}$ and $\mathrm{BaSnO}_{3}$ crystals might be different than that of La-doped $\mathrm{BaSnO}_{3}$ where the La-doping takes place at the $\mathrm{Ba}$ subnetwork, while the transport through the Sn-subnetwork.

A comparison of the $\mu_{\mathrm{H}-\mathrm{Max}}$ values from the present study and those ever reported for the compounds discussed here along with the predicted values is summarized in Table 4. It shows that $\mu_{\mathrm{H}-\mathrm{Max}}$ values for bulk single crystals may reach those concluded as intrinsic limits (predicted). However, not all predicted values include all possible scattering mechanisms. Also, thin films of high structural quality and purity (here $\beta-\mathrm{Ga}_{2} \mathrm{O}_{3}$ and $\mathrm{In}_{2} \mathrm{O}_{3}$ ) resulted in higher $\mu_{\mathrm{H}-\mathrm{Max}}$ values as compared with bulk crystals.
TABLE 4: Maximum values of Hall electron mobility $\mu_{\mathrm{H}-\mathrm{Max}}$ at RT measured on bulk TSO single crystals (present work) compared with those reported in the literature and predicted.

\begin{tabular}{|c|c|c|c|}
\hline Compound & $\begin{array}{l}\mu_{\mathrm{H}-\mathrm{Max}}-\text { present work } \\
{\left[\mathrm{cm}^{2} \mathrm{~V}^{-1} \mathrm{~s}^{-1}\right]}\end{array}$ & $\mu_{\mathrm{H}-\mathrm{Max}}-$ literature $\left[\mathrm{cm}^{2} \mathrm{~V}^{-1} \mathrm{~s}^{-1}\right]$ & $\begin{array}{c}\mu_{\mathrm{H}-\mathrm{Max}}- \\
\text { predicted } \\
{\left[\mathrm{cm}^{2} \mathrm{~V}^{-1} \mathrm{~s}^{-1}\right]}\end{array}$ \\
\hline$\beta-\mathrm{Ga}_{2} \mathrm{O}_{3}$ & 160 & 194 Films-MOCVD [94] & $220[95]$ \\
\hline $\ln _{2} \mathrm{O}_{3}$ & 213 & 226 Films-PAMBE [96] & $274[96]$ \\
\hline $\mathrm{ZnO}$ & 187 & 230 Bulk-hydrothermal [97] & $233[98]$ \\
\hline $\mathrm{SnO}_{2}$ & 240 & 260 Bulk-CVT [99] & $265[100]$ \\
\hline $\mathrm{ZnSnO}_{3}$ & 126 & 25 Films-sputtering [101] & - \\
\hline $\mathrm{BaSnO}_{3}$ & 225 & 320 Bulk-flux [102] & $330[103]$ \\
\hline $\mathrm{MgGa}_{2} \mathrm{O}_{4}$ & 7 & - & - \\
\hline $\mathrm{Zn}_{1-\mathrm{x}} \mathrm{Mg}_{\mathrm{x}} \mathrm{Ga}_{2} \mathrm{O}_{4}$ & 32 & - & - \\
\hline $\mathrm{ZnGa}_{2} \mathrm{O}_{4}$ & 107 & 20 Films-MOCVD [104] & - \\
\hline $\mathrm{InGaZnO}_{4}$ & 127 & $\approx 100$ Bulk-OFZ [93] & $150-200[105]$ \\
\hline
\end{tabular}

MOCVD metal-organic chemical vapour deposition, PAMBE plasma-assisted molecular beam epitaxy, CVT chemical vapour transport. 


\section{Summary}

In the present work, we summarized basic electrical properties, i.e. free electron concentration $\left(n_{\mathrm{e}}\right)$ and Hall electron mobility $\left(\mu_{\mathrm{H}}\right)$, of bulk single crystals of the TSOs, including binary $\left(\beta-\mathrm{Ga}_{2} \mathrm{O}_{3}, \mathrm{In}_{2} \mathrm{O}_{3}, \mathrm{ZnO}, \mathrm{SnO}_{2}\right)$, ternary $\left(\mathrm{ZnSnO}_{3}, \mathrm{BaSnO}_{3}, \mathrm{MgGa}_{2} \mathrm{O}_{4}, \mathrm{ZnGa}_{2} \mathrm{O}_{4}\right)$, and quaternary $\left(\mathrm{Zn}_{1-\mathrm{x}} \mathrm{Mg}_{\mathrm{x}} \mathrm{Ga}_{2} \mathrm{O}_{4}, \mathrm{InGaZnO}_{4}\right)$ systems. Nine out of ten investigated compounds were grown directly from the melt at temperatures between 1700 and $2000^{\circ} \mathrm{C}$, and one $\left(\mathrm{SnO}_{2}\right)$ from the gas phase at the temperature of about $1600^{\circ} \mathrm{C}$.

A large data set of electrical measurements revealed n-type conductivity of all of the compounds. $n_{\mathrm{e}}$ values span for the investigated compounds between $5 \times 10^{15}$ and $5 \times 10^{20} \mathrm{~cm}^{-3}$ with $\beta-\mathrm{Ga}_{2} \mathrm{O}_{3}$ and $\mathrm{In}_{2} \mathrm{O}_{3}$ having the widest doping range, above 3 and above 2 orders of magnitude, respectively. Bulk $\beta-\mathrm{Ga}_{2} \mathrm{O}_{3}, \mathrm{SnO}_{2}, \mathrm{BaSnO}_{3}, \mathrm{MgGa}_{2} \mathrm{O}_{4}, \mathrm{ZnGa}_{2} \mathrm{O}_{4}$, and $\mathrm{Zn}_{1-\mathrm{x}} \mathrm{Mg}_{\mathrm{x}} \mathrm{Ga}_{2} \mathrm{O}_{4}$ single crystals can be turned to electrical insulators, while others always remain at electrically conducting state independent on doping and/or annealing. The highest $n_{\mathrm{e}}$ values $>10^{20} \mathrm{~cm}^{-3}$ were measured for bulk $\mathrm{InGaZnO}_{4}$ and $\mathrm{ZnSnO}_{3}$ without any intentional doping.

The highest values of $\mu_{\mathrm{H}}>200 \mathrm{~cm}^{2} \mathrm{~V}^{-1} \mathrm{~s}^{-1}$ were measured for $\mathrm{SnO}_{2}, \mathrm{BaSnO}_{3}$, and $\mathrm{In}_{2} \mathrm{O}_{3}$ single crystals. Ga-based spinels containing magnesium showed the lowest $\mu_{\mathrm{H}}$ values $\leq 32$ $\mathrm{cm}^{2} \mathrm{~V}^{-1} \mathrm{~s}^{-1}$. Some of the compounds, in particular all binary systems, well follow the $\mu_{\mathrm{H}}-n_{\mathrm{e}}$ relation limited by phonon scattering at lower doping range $\left(n_{\mathrm{e}}<10^{18} \mathrm{~cm}^{-3}\right)$ and by impurity scattering at higher doping range $\left(n_{\mathrm{e}}>10^{18} \mathrm{~cm}^{-3}\right)$. This relation is different, in particular for $\mathrm{ZnGa}_{2} \mathrm{O}_{4}$ and $\mathrm{InGaZnO}_{4}$, likely due to structural defects and secondary phase traces, and for $\mathrm{BaSnO}_{3}$ that depends on the doping level.

\section{Acknowledgments}

This work was partly performed in the framework of GraFOx, a Leibniz-Science Campus partially funded by the Leibniz Association-Germany. The authors express their gratitude to Dr. Andreas Popp from the Leibniz-Institut für Kristallzüchtung for critical reading of the manuscript.

\section{Funding}

Open Access funding enabled and organized by Projekt DEAL.

\section{Data availlability}

Data will be made available on reasonable request.

\section{Declarations}

Conflict of interest The authors declare no conflict of interest.

\section{Open Access}

This article is licensed under a Creative Commons Attribution 4.0 International License, which permits use, sharing, adaptation, distribution and reproduction in any medium or format, as long as you give appropriate credit to the original author(s) and the source, provide a link to the Creative Commons licence, and indicate if changes were made. The images or other third party material in this article are included in the article's Creative Commons licence, unless indicated otherwise in a credit line to the material. If material is not included in the article's Creative Commons licence and your intended use is not permitted by statutory regulation or exceeds the permitted use, you will need to obtain permission directly from the copyright holder. To view a copy of this licence, visit http://creativecommons.org/ licenses/by/4.0/.

\section{References}

1. H. Ohta, H. Hosono, Mater. Today 7, 42-51 (2004)

2. Ü. Özgür, Y.I. Alivov, C. Liu, A. Teke, M.A. Reshchikov, S. Doğan, V. Avrutin, S.-J. Cho, H. Morkoç, J. Appl. Phys. 98, 041301 (2005)

3. M. Grundmann, H. Frenzel, A. Lajn, M. Lorenz, F. Schein, H. von Wenckstern, Phys. Status Solidi A 207, 1437-1449 (2010)

4. M. Grundmann, F. Klüpfel, R. Karsthof, P. Schlupp, F.-L. Schein, D. Splith, C. Yang, S. Bitter, H. von Wenckstern, J. Phys. D: Appl. Phys. 49, 213001 (2016)

5. E. Fortunato, P. Barquinha, R. Martins, Adv. Mater. 24, 2945-2986 (2012)

6. H. von Wenckstern, Adv. Electron. Mater. 3, 1600350 (2017)

7. S. Lee, S. Jeon, R. Chaji, A. Nathan, Proc. IEEE 103, 644-664 (2015)

8. M. Higashiwaki, H. Murakami, Y. Kumagai, A. Kuramata, Jpn. J. Appl. Phys. 55, 1202A1 (2016)

9. S.J. Pearton, J. Yang, P.H. Cary IV., F. Ren, J. Kim, M.J. Tadjer, M.A. Mastro, Appl. Phys. Rev. 5, 011301 (2018)

10. Z. Galazka, Semicond. Sci. Technol. 33, 113001 (2018)

11. A.E. Delahoy, S. Guo, Transparent conducting oxides for photovoltaics, in Handbook of Photovoltaic Science and Engineering, 2nd edn., ed. by A. Luque, S. Hegedus (Wiley, Hoboken, 2011)

12. D.S. Ginley, H. Hosono, D.C. Paine (eds.), Handbook of Transparent Conductors (Springer, Boston, 2010)

13. P. Barquinha, R. Martins, L. Pereira, E. Fortunato, Transparent Oxide Electronics: From Materials to Devices (Wiley, Hoboken, 2012)

14. S. Pearton, F. Ren, M. Mastro (eds.), Gallium Oxide Technology, Devices and Applications (Elsevier, Amsterdam, 2019)

15. M. Higashiwaki, S. Fujita (eds.), Gallium Oxide, Material Properties, Crystal Growth, and Devices (Springer, Cham, 2020) 
16. Z. Galazka, Transparent Semiconducting Oxides-Bulk Crystal Growth and Fundamental Properties (Jenny Stanford Publishing, Dubai, 2020)

17. C. Janowitz, V. Scherer, M. Mohamed, A. Krapf, H. Dwelk, R. Manzke, Z. Galazka, R. Uecker, K. Irmscher, R. Fornari, M. Michling, D. Schmeißer, J.R. Weber, J.B. Varley, C.G. Van de Walle, New J. Phys. 13, 085014 (2011)

18. K. Irmscher, M. Naumann, M. Pietsch, Z. Galazka, R. Uecker, T. Schulz, R. Schewski, M. Albrecht, R. Fornari, Phys. Status Solidi A 211, 54-58 (2014)

19. M. Feneberg, J. Nixdorf, C. Lidig, R. Goldhahn, Z. Galazka, O. Bierwagen, J.S. Speck, Phys. Rev. B 93, 045203 (2016)

20. H. Schulz, K.H. Thiemann, Solid State Commun. 32, 783-785 (1979)

21. W.S. Baer, Phys. Rev. 154, 785-789 (1967)

22. K.J. Button, D.R. Cohn, M. von Ortenverger, B. Lax, E. Mollwo, R. Helbig, Phys. Rev. Lett. 28, 1637-1639 (1972)

23. R.L. Wieher, Phys. Rev. 152, 736-739 (1966)

24. J. Tang, L.Y. Deng, C.B. Tay, X.H. Zhang, J.W. Chai, H. Qin, H.W. Liu, T. Venkatesan, S.J. Chua, J. Appl. Phys. 115, 033111 (2014)

25. Y. Wang, J. Zhu, W. Tang, Appl. Phys. Lett. 104, 212103 (2014)

26. A. Bolzan, C. Fong, B.J. Brendan, J. Kennedy, C.J. Howard, Acta Cryst. B 53, 373-380 (1997)

27. M. Feneberg, C. Lidig, K. Lange, M.E. White, M.Y. Tsai, J.S. Speck, O. Bierwagen, R. Goldhahn, Phys. Status Solidi A 211, 82-86 (2014)

28. M. Feneberg, C. Lidig, M.E. White, M.Y. Tsai, J.S. Speck, O. Bierwagen, Z. Galazka, R. Goldhahn, APL Mater. 7, 022508 (2019)

29. Y. Inaguma, M. Yoshida, T. Katsumata, J. Am. Chem. Soc. 130, 6704-6705 (2008)

30. M. Miyauchi, Z. Liu, Z.-G. Zhao, S. Anandan, K. Hara, Chem. Commun. 46, 1529-1531 (2010)

31. K.P. Ong, X. Fan, A. Subedi, M.B. Sullivan, D.J. Singh, APL Mater. 3, 062505 (2015)

32. A.J. Smith, A.J.E. Welch, Acta Crystallogr. 13, 653-656 (1960)

33. Z. Galazka, R. Uecker, K. Irmscher, D. Klimm, R. Bertram, A. Kwasniewski, M. Naumann, R. Schewski, M. Pietsch, U. Juda, A. Fiedler, M. Albrecht, S. Ganschow, T. Markurt, C. Guguschev, M. Bickermann, J. Phys. Condens. Matter. 29, 075701 (2017)

34. C.A. Niedermeier, S. Rhode, S. Fearn, K. Ide, M.A. Moram, H. Hiramatsu, H. Hosono, T. Kamiya, Appl. Phys. Lett. 108, 172101 (2016)

35. C.A. Niedermeier, S. Rhode, K. Ide, H. Hiramatsu, H. Hosono, T. Kamiya, M.A. Moram, Phys. Rev. B 95, 161202 (2017)

36. L. Schwarz, Z. Galazka, T.M. Gesing, D. Klimm, Cryst. Res. Technol. 50, 961-966 (2015)

37. Z. Galazka, D. Klimm, K. Irmscher, R. Uecker, M. Pietsch, R. Bertram, M. Naumann, M. Albrecht, A. Kwasniewski, R.
Schewski, M. Bickermann, Phys. Status Solidi A 212, 1455-1460 (2015)

38. Z. Galazka, S. Ganschow, K. Irmscher, D. Klimm, M. Albrecht, R. Schewski, M. Pietsch, T. Schulz, A. Dittmar, A. Kwasniewski, R. Grueneberg, S. Bin Anooz, A. Popp, U. Juda, I.M. Hanke, T. Schroeder, M. Bickermann, Prog. Cryst. Growth Charact. Mater. 67, 100511 (2021)

39. Z. Galazka, S. Ganschow, R. Schewski, K. Irmscher, D. Klimm, A. Kwasniewski, M. Pietsch, A. Fiedler, I. Schulze-Jonack, M. Albrecht, T. Schröder, M. Bickermann, APL Mater. 7, 022512 (2019)

40. S.K. Sampath, D.G. Kanhere, R. Pandey, J. Phys. Condens. Matter. 11, 3635-3644 (1999)

41. H. Dixit, N. Tandon, S. Cottenier, R. Saniz, D. Lamoen, B. Partoens, V. Van Speybroeck, M. Waroquier, New J. Phys. 13, 063002 (2011)

42. W. Assenmacher, G. Schnakenburg, Y. Michiue, Y. Kanke, N. Kimizuka, W. Mader, J. Solid State Chem. 215, 176-183 (2014)

43. K. Iordanidou, C. Persson, Mater. Sci. Semicond. Process. 121, 105297 (2021)

44. Z. Galazka, R. Uecker, K. Irmscher, M. Albrecht, D. Klimm, M. Pietsch, M. Brützam, R. Bertram, S. Ganschow, R. Fornari, Cryst. Res. Technol. 45, 1229-1236 (2010)

45. Z. Galazka, K. Irmscher, R. Uecker, R. Bertram, M. Pietsch, A. Kwasniewski, M. Naumann, T. Schulz, R. Schewski, D. Klimm, M. Bickermann, J. Cryst. Growth 404, 184-191 (2014)

46. Z. Galazka, R. Uecker, D. Klimm, K. Irmscher, M. Naumann, M. Pietsch, A. Kwasniewski, R. Bertram, S. Ganschow, M. Bickermann, ECS J. Solid State Sci. Technol. 6, Q3007-Q3011 (2017)

47. Z. Galazka, S. Ganschow, A. Fiedler, R. Bertram, D. Klimm, K. Irmscher, R. Schewski, M. Pietsch, M. Albrecht, M. Bickermann, J. Cryst. Growth 486, 82-90 (2018)

48. Z. Galazka, K. Irmscher, R. Schewski, I.M. Hanke, M. Pietsch, S. Ganschow, D. Klimm, A. Dittmar, A. Fiedler, T. Schroeder, M. Bickermann, J. Cryst. Growth 529, 125297 (2020)

49. Z. Galazka, R. Schewski, K. Irmscher, W. Drozdowski, M.E. Witkowski, M. Makowski, A.J. Wojtowicz, I.M. Hanke, M. Pietsch, T. Schulz, D. Klimm, S. Ganschow, A. Dittmar, A. Fiedler, T. Schroeder, M. Bickermann, J. Alloy. Compd. 818, 152842 (2020)

50. Z. Galazka, Czochralski method, in Gallium Oxide: Crystal Growth, Materials Properties, and Devices. ed. by M. Higashiwaki, S. Fujita (Springer, Cham, 2020), pp. 15-36

51. Z. Galazka, R. Uecker, K. Irmscher, D. Schulz, D. Klimm, M. Albrecht, M. Pietsch, S. Ganschow, A. Kwasniewski, R. Fornari, J. Cryst. Growth 362, 349-352 (2013)

52. Z. Galazka, R. Uecker, R. Fornari, J. Cryst. Growth 388, 61-69 (2014)

53. Z. Galazka, K. Irmscher, M. Pietsch, T. Schulz, R. Uecker, D. Klimm, R. Fornari, CrystEngComm 15, 2220-2226 (2013) 
54. D. Schulz, S. Ganschow, D. Klimm, M. Neubert, M. Rossberg, M. Schmidbauer, R. Fornari, J. Cryst. Growth 296, 27-30 (2006)

55. D. Schulz, S. Ganschow, D. Klimm, K. Struve, J. Cryst. Growth 310, 1832-1835 (2008)

56. D. Klimm, S. Ganschow, D. Schulz, R. Fornari, J. Cryst. Growth 310, 3009-3013 (2008)

57. D. Schulz, S. Ganschow, D. Klimm, Mater. Res. Soc. Symp. Proc. 1201, 120-H06-10 (2010)

58. K. Jacobs, D. Schulz, D. Klimm, S. Ganschow, Solid State Sci. 12, 307-310 (2010)

59. Z. Galazka, R. Uecker, D. Klimm, K. Irmscher, M. Pietsch, R. Schewski, M. Albrecht, A. Kwasniewski, S. Ganschow, D. Schulz, C. Guguschev, R. Bertram, M. Bickermann, R. Fornari, Phys. Status Solidi A 211, 66-73 (2014)

60. Z. Galazka, I.M. Hanke; Leibniz-Institut für Kristallzüchtung, Berlin, Germany (2019), unpublished data.

61. Z. Galazka, I.M. Hanke; Leibniz-Institut für Kristallzüchtung, Berlin, Germany (2016), unpublished data.

62. K. Hoshikawa, E. Ohba, T. Kobayashi, J. Yanagisawa, C. Miyagawa, Y. Nakamura, J. Cryst. Growth 447, 36-41 (2016)

63. E.G. Villora, K. Shimamura, Y. Yoshikawa, T. Ujiie, K. Aoki, Appl. Phys. Lett. 92, 202120 (2008)

64. J.B. Varley, H. Peelaers, A. Janotti, C.G. Van de Walle, J. Phys.: Condens. Matter 23, 334212 (2011)

65. A. Kuramata, K. Koshi, S. Watanabe, Y. Yamaoka, T. Masui, S. Yamakoshi, Jpn. J. Appl. Phys. 55, 1202A2 (2016)

66. E. Ahmadi, O.S. Koksaldi, S.W. Kaun, Y. Oshima, D.B. Short, U.K. Mishra, J.S. Speck, Appl. Phys. Express 10, 041102 (2017)

67. M. Saleh, A. Bhattacharyya, J.B. Varley, S. Swain, J. Jesenovec, S. Krishnamoorthy, K. Lynn, Appl. Phys. Express 12, 085502 (2019)

68. M. Saleh, J.B. Varley, J. Jesenovec, A. Bhattacharyya, S. Krishnamoorthy, S. Swain, K. Lynn, Semicond. Sci. Technol. 35, 04LT01 (2020)

69. O. Bierwagen, Semicond. Sci. Technol. 30, 024001 (2015)

70. S. Limpijumnong, P. Reunchan, A. Janotti, C.G. Van de Walle, Phys. Rev. B 80, 193202 (2009)

71. J.B. Varley, H. Peelaers, A. Janotti, C.G. Van de Walle, J. Phys. Condens. Matter 23, 334212 (2011)

72. P. Ágoston, P. Erhart, A. Klein, K. Albe, J. Phys. Condens. Matter 21, 455801 (2009)

73. R. Helbig, J. Cryst. Growth 15, 25-31 (1972)

74. C.G. Van de Walle, Phys. Rev. Lett. 85, 1012-1015 (2000)

75. E.V. Lavrov, F. Herklotz, J. Weber, Phys. Rev. B 79, 165210 (2009)

76. D.C. Look, J.W. Hemsky, J.R. Sizelove, Phys. Rev. Lett. 82, 2552-2555 (1999)

77. J.B. Varley, A. Janotti, C.G. Van de Walle, Phys. Rev. B 81, $245216(2010)$

78. Z. Remes, M. Vanecek, H.M. Yates, P. Evans, D.W. Sheel, Thin Solid Films 517, 6287-6289 (2009)
79. D.O. Scanlon, G.W. Watson, J. Mater. Chem. 22, 25236 (2012)

80. P.D.C. King, R.L. Lichti, Y.G. Celebi, J.M. Gil, R.C. Vilão, H.V. Alberto, J.P. Duarte, D.J. Payne, R.G. Egdell, I. McKenzie, C.F. McConville, S.F.J. Cox, T.D. Veal, Phys. Rev. B 80, 081201 (2009)

81. X. Luo, Y.S. Oh, A. Sirenko, P. Gao, T.A. Tyson, K. Char, S.-W. Cheong, Appl. Phys. Lett. 100, 172112 (2012)

82. E. McCalla, D. Phelan, M.J. Krogstad, B. Dabrowski, C. Leighton, Phys. Rev. Meter. 2, 084601 (2018)

83. H.J. Kim, J. Kim, T.H. Kim, W.-J. Lee, B.-G. Jeon, J.-Y. Park, W.S. Choi, D.W. Jeong, S.H. Lee, J. Yu, T.W. Noh, K.H. Kim, Phys. Rev. B 88, 125204 (2013)

84. D.O. Scanlon, Phys. Rev. B 87, 161201 (2013)

85. S.C. Badescu, M.D. Santia, D.C. Look, K.D. Leedy; contribution at SPIE Photonic West, February 2020, San Francisco, entitled "First-principles modelling of native point defects in zinc gallate"

86. A. Murat, A.U. Adler, T.O. Mason, J.E. Medvedeva, J. Am. Chem. Soc. 135, 5685-5692 (2013)

87. M. Baldini, M. Albrecht, A. Fiedler, K. Irmscher, R. Schewski, G. Wagner, ECS J. Solid State Sci. Technol. 6, Q3040-Q3044 (2017)

88. O. Bierwagen, J.S. Speck, Phys. Status Solidi A 211, 48-53 (2014)

89. H. Tampo, H. Shibata, P. Fons, A. Yamada, K. Matsubara, K. Iwata, K. Tamura, H. Takasu, S. Niki, J. Cryst. Growth 278, 268-272 (2005)

90. M.E. White, O. Bierwagen, M.Y. Tsai, J.S. Speck, J. Appl. Phys. 106, 093704 (2009)

91. H.F. Wang, Q.Z. Liu, F. Chen, G.Y. Gao, W. Wu, X.H. Chen, J. Appl. Phys. 101, 106105 (2007)

92. M. Albrecht, R. Schewski, K. Irmscher, Z. Galazka, T. Markurt, M. Naumann, T. Schulz, R. Uecker, R. Fornari, S. Meuret, M. Kociak, J. Appl. Phys. 115, 053504 (2014)

93. Y. Tanaka, K. Wada, Y. Kobayashi, T. Fujii, S.J. Denholme, R. Sekine, N. Kase, N. Kimizuka, N. Miyakawa, CrystEngComm 21, 2985-2993 (2019)

94. Z. Feng, A.F.M.A.U. Bhuiyan, Z. Xia, W. Moore, Z. Chen, J.F. McGlone, D.R. Daughton, A.R. Arehart, S.A. Ringel, S. Rajan, H. Zhao, Phys. Status Solidi RRL 14, 2000145 (2020)

95. N. Ma, N. Tanen, A. Verma, Z. Guo, T. Luo, H. (Grace) Xing, D. Jena, Appl. Phys. Lett. 109, 212101 (2016)

96. O. Bierwagen, J.S. Speck, Appl. Phys. Lett. 97, 072103 (2010)

97. M.W. Allen, P. Miller, R.J. Reeves, S.M. Durbin, Appl. Phys. Lett. 90, $062104(2007)$

98. X. Yang, C. Xu, N.C. Giles, J. Appl. Phys. 104, 073727 (2008)

99. C.G. Fonstad, R.H. Rediker, J. Appl. Phys. 42, 2911-2918 (1971)

100. Y. Hu, J. Hwang, Y. Lee, P. Conlin, D.G. Schlom, S. Datta, K. Cho, J. Appl. Phys. 126, 185701 (2019)

101. F.-Y. Wu, J.-W. Li, Y. Qi, W.-T. Ding, Y.-Y. Guo, Y.-W. Zhou, Acta Metall. Sin. 29, 827-833 (2016) 
102. H.J. Kim, U. Kim, H.M. Kim, T.H. Kim, H.S. Mun, B.-G. Jeon, K.T. Hong, W.-J. Lee, C. Ju, K.H. Kim, K. Char, Appl. Phys. Express 5, 061102 (2012)

103. K. Krishnaswamy, B. Himmetoglu, Y. Kang, A. Janotti, C.G. Van de Walle, Phys. Rev. B 95, 205202 (2017)
104. D.C. Look, K.D. Leedy, R.-H. Horng, M.D. Santia, S.C. Badescu, Appl. Phys. Lett. 116, 252104 (2020)

105. Y. Jegal, A.H. Kulahlioglu, C.-K. Baek, B.D. Kong, IEEE Electron. Device Lett. 41, 872-875 (2020) 